\title{
Design of Groundwater Filtration Technology to Meet the Clean Water Needs of Rural Communities Using Quality Function Deployment
}

\author{
Sriyanto Sriyanto ${ }^{1, *}$, Ary Arvianto ${ }^{1}$, and Muhammad Ihsan Hidayat ${ }^{1}$ \\ ${ }^{1}$ Department of Industrial Engineering, Faculty of Engineering, Diponegoro University, Semarang - Indonesia
}

\begin{abstract}
The provision of clean water for all Indonesians is one of the objectives of the government that is still constrained by the limitations of the existing water supply infrastructure. Some areas, especially rural or remote areas, are still hard to reach by the clean water facilities of the Regional Water Company. Whereas the groundwater resources in this region are abundant but can't be explored optimally to meet the needs of clean water and proper consumption for the surrounding community. The availability of water is not balanced with its quality, especially as qualified water for consumption. Some other characteristics of rural areas such as poor sanitation and the presence of agricultural waste pollutants, result in groundwater quality being further away from the standard of consumption. Although there are some commercial water filtration technologies available, they are generally expensive, with limited capacity, and not intended for mass use. For that reason, a new breakthrough, by designing proper technology, which is not only affordable but also easy to use and have sufficient capacity to meet the needs of the community. This research used Quality Function Deployment followed by Functional Analysis Systems Technique to get the character of the user and design requirement of groundwater filtration technology which suitable with the community needs and water quality condition in rural areas. The result is a design of filtration technology consists of five main modules, namely filtration module, information module high voltage module, reactor module, and rack module. This design is expected to be the basis for developing clean water technologies for people in rural areas or others that are difficult to reach by the Regional Water Company infrastructure.
\end{abstract}

Keywords: Groundwater filtration; Rural areas; Quality Function Deployment.

\section{Introduction}

One principle in building low carbon society is by how to coexistence with nature especially in maintaining the natural environment that is essential for human society. Human life cannot sustain without the availability of water. In general, humans use water for drinking, washing, bathing and other household needs. These needs continue to increase as the population increases and the more varied patterns of human life.

Sustainable supplies of clean water are vital for the health, environment and economy of the community. The provision of clean water for all Indonesians is one of the objectives of the government that is still constrained by the limitations of existing water supplies and infrastructures. Some areas, especially rural or remote areas, are still hard to reach by the clean water facilities of the Regional Water Company. Whereas the groundwater resources in this region are abundant but can't be explored optimally to meet the needs of clean water and proper consumption for the surrounding community. The availability of water is not balanced with its quality, especially as qualified water for consumption.
The use of dug wells as a water source is the most preferred alternative, especially in rural areas. Ground water sources obtained this way provide water from soil layers relatively close to the ground. However, this may trigger either contamination from seepage derived from human, animal or borehole waste, either because the floor or sewer is not water-resistant.

Limited access to adequate water supplies from quality that meets acceptable standards leads to a variety of diseases related to water and sanitation that affect public health [1]. Many people, usually in the rural areas, are affected most due to inadequate resources to invest in water supply and sanitation [2]. This is made worse by the presence of polluted agricultural waste, resulting in groundwater quality that is far from standard consumption.

In the process of waste water treatment, there are various requirements that must be met, among others; physics, chemistry, and bacteriology which is a unity. If any of the conditions are not met, then the water becomes unfit for consumption. Thus, appropriate technology is needed for waste water treatment, from filtration process, to pollutant or microorganism reduction.

\footnotetext{
* Corresponding author: sriyanto@,ft.undip.ac.id
} 
Although there are several commercial water filtration technologies available, they are generally expensive, with limited capacity, and are not intended for mass use. Therefore, a new breakthrough is needed, that is, by listening to the needs of the community.

\section{Methods}

\subsection{Water Treatment}

The water treatment process is intended to process, repair, and condition various water sources (such as rivers, groundwater, and wastewater) into water that is suitable for disposal and consumption. In this research, the water treatment process refers to the water treatment scheme commonly used in river water treatment facilities.

The scheme generally consists of five main processes described as follows:

\section{A. Coagulation}

Is a process of colloidal destabilization and suspended particles in the water due to the uniform mixing with certain chemical compounds (coagulants) with a rapid agitation process.

\section{B. Flocculation}

Flucolation is a slow stirring process that serves to accelerate the incorporation of colloidal particles to form large particles that easily and quickly settle.

\section{Sedimentation}

Sedimentation is an operation designed to remove most of the solids that can gravitate.

\section{Filtration}

Filtration serves as a fine floccurrent filter still present in non-deposited water in the sedimentation process. This process can filter bacteria or microorganisms that exist in water.

E. Desinfectant

Disinfection process serves to eliminate, disable, or kill pathogens of microorganisms. In this process microorganisms are disabled or eliminated to prevent the development of a population of microorganisms in water.

The existence of microorganisms or bacteria in the water can have a serious impact, especially for vulnerable members of society such as children or elderly people. Conventional water treatments mainly emphasize the removal of colloidal particles from raw water. While upstream treatment processes prior to disinfection are not capable enough in eliminating the microorganisms. Microorganisms in water are proven to be effectively eliminated by a pulsed high voltage plasma system [3].

\subsection{Quality Function Deployment}

Quality function deployment (QFD) is an analytical tool that is especially used in new product development or product improvement. QFD use a systematic approach for identifying and prioritizing customer requirements, translating those into design requirements to fulfil the expectation [4-6].
The house of quality (Fig. 1) is a diagram that used to describe the value of the factors involved, including customer and design requirements, relationships between both requirements, and correlations among the design requirements $[7,8]$.

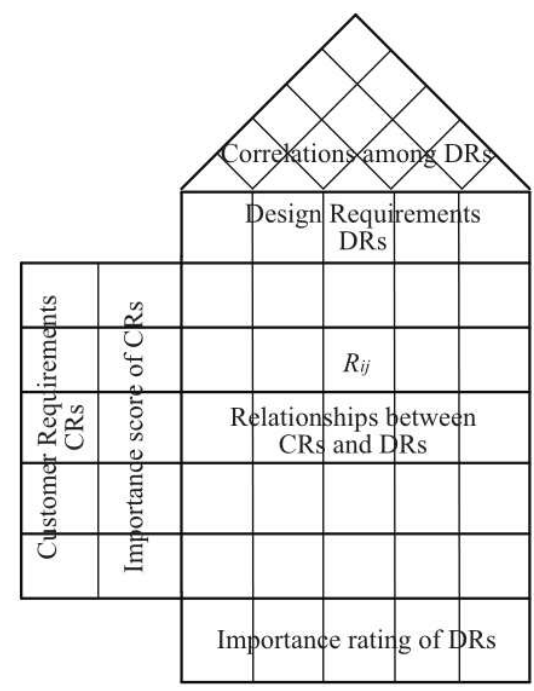

Fig. 1. The house of quality.

\section{Results and discussion}

\subsection{Questionnaires}

This research conducted in a community at boarding school in the rural area, Jetis Trawas, Gunungpati Semarang. There are about 228 people live in the community. The initial step is established face validity by an interview the consumers including the principal, operator and other users. This process determines the initial needs of consumers and captures the abstract needs that may not be explained, as shown in Table 1 .

Table 1. Custormer needs interpretation.

\begin{tabular}{|c|c|}
\hline Interpretation & Customer statement \\
\hline Product longevity & $\begin{array}{c}\text { Equipment useful life more than } \\
\text { three years }\end{array}$ \\
\hline Easy to repair & General instrument for repair \\
\cline { 2 - 2 } $\begin{array}{c}\text { Spare parts are } \\
\text { widely available }\end{array}$ & Standardized equipment parts \\
\hline $\begin{array}{c}\text { Easy to maintain } \\
\text { Performance } \\
\text { indicator }\end{array}$ & General instrument for maintenance \\
\hline $\begin{array}{c}\text { Provides clean up- } \\
\text { related warning }\end{array}$ & $\begin{array}{c}\text { Equipment showing critical } \\
\text { information performance }\end{array}$ \\
\hline Easy cleaning & Equipment showing warning \\
\hline $\begin{array}{c}\text { Long cleaning } \\
\text { period }\end{array}$ & $\begin{array}{c}\text { Support easy cleaning operation } \\
\text { equipment should be cleaned }\end{array}$ \\
\hline $\begin{array}{c}\text { Supports the } \\
\text { existing system }\end{array}$ & $\begin{array}{c}\text { Standard interface of the equipment } \\
\text { in assembly process }\end{array}$ \\
\hline Affordable price & Price of the equipment is affordable \\
\hline Power-saving usage & The use of the minimum power \\
\hline
\end{tabular}


Initial questionnaire have been designed and pilot test conducted. And by using Cronbach's Alpha, none of these variables below the $r$ value, but after reliability test, there is one variable excluded, that is the long cleaning period attribute.

The next process is to determine user satisfaction level as a measure of how important a variable needs in product design, followed by determination of targeted goals for the needs fulfillment. Then, sales factor as marketing power to show product advantages against competitors' products taken into account.

The last processes is the compilation of normalized load values against the attribute values that have been obtained. This process aims to determine the priority of the attribute and see how much attribute affects the total overall quality attribute, as shown in Fig. 2.

After the design reguirement obtained, then Functional Analysis Systems Technique (FAST) is used to map the functional system. FAST is a powerful mapping technique that graphically models products and processes in function terms and identifies function dependencies [9]. The resulted FAST diagram is showed in Fig. 3.

Finally, the alternative technology available for the groundwater filtration functions is selected, as shown in Fig. 4. The system designed, as shown in Fig. 5, consists of five main modules that are as follows:

1. Filtration module to enhance water quality by particle absorption and disc filtration

2. Information module to inform the filtration performance by color signifier and buzzer

3. High voltage module to magnify the input power for electrical discharge
4. Reactor module to kill microorganisms or organic pollutans by oxidation

5. Rack module to assembled four modules above into one ergonomic system

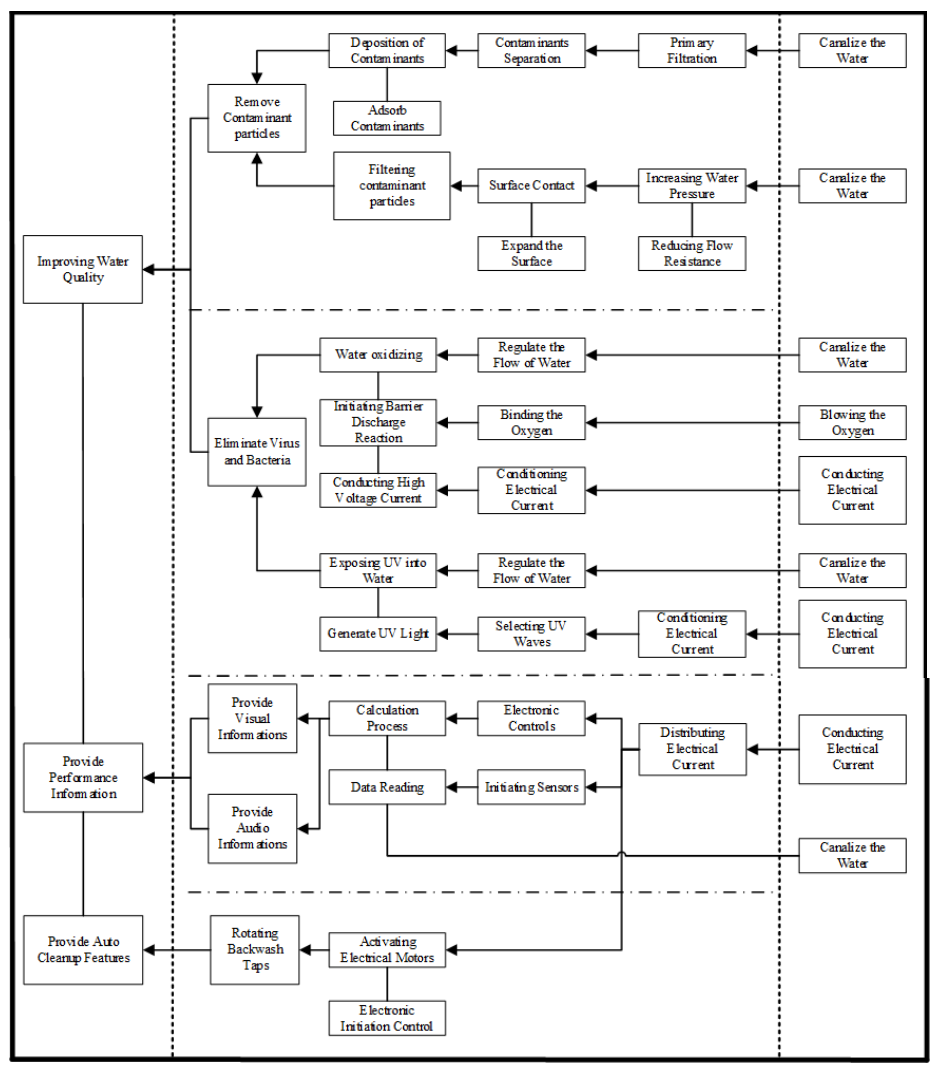

Fig. 3. FAST diagram.

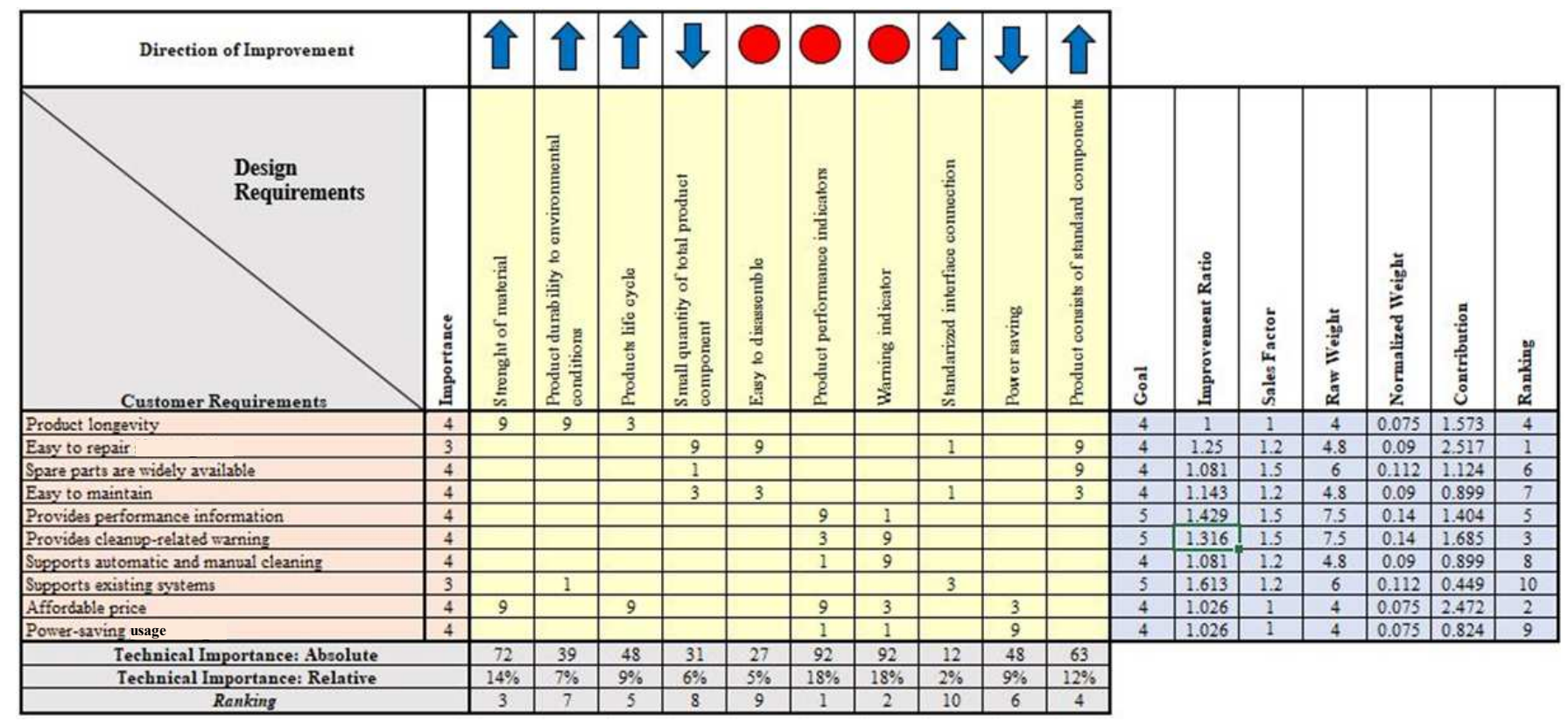

Fig. 2. QFD result. 


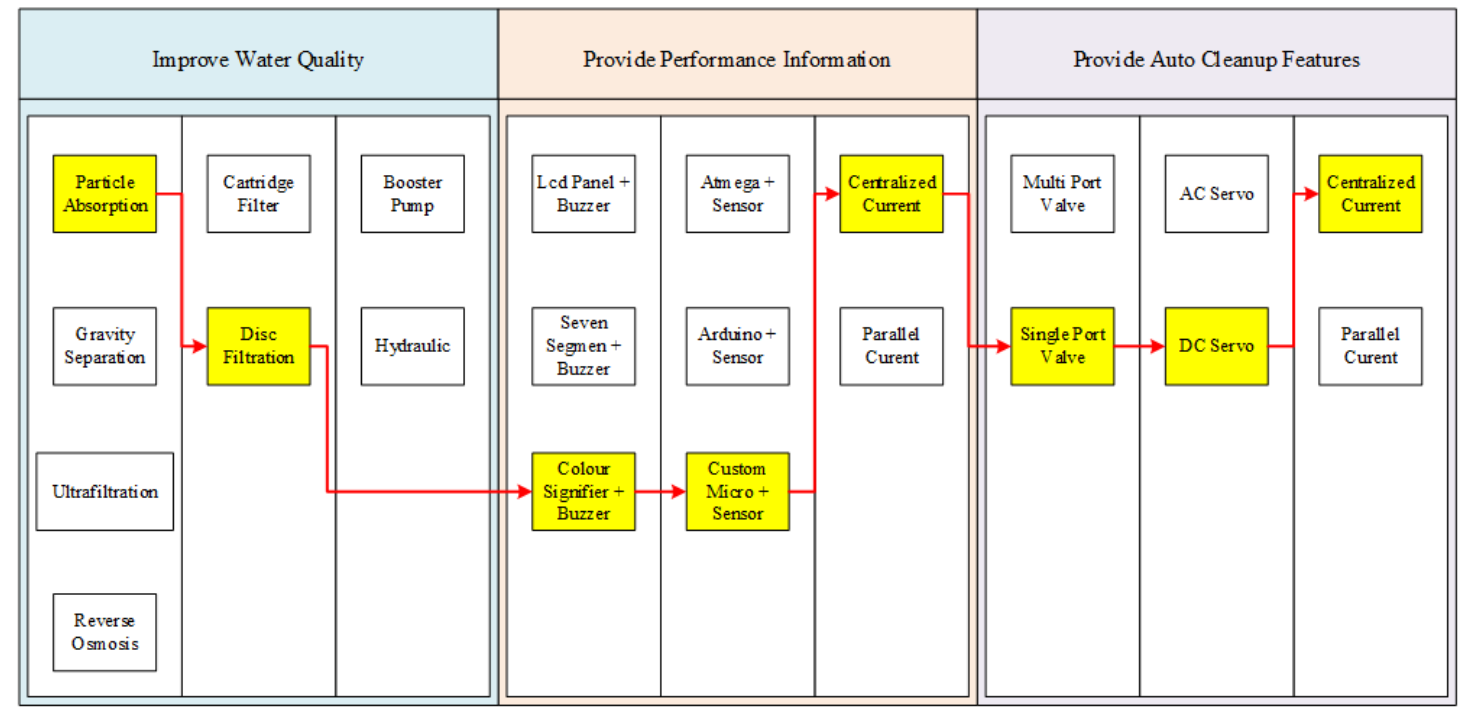

Fig. 4. Technology alternative selection

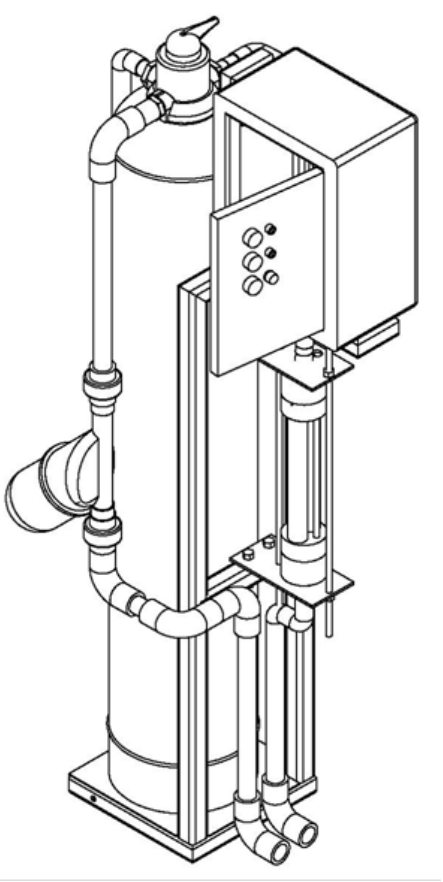

Fig. 5. Groundwater filtration technology design.

\section{Conclusion}

The Quality Function Deployment method can translate the rural communities requirements of groundwater filtration technology into design requirements successfully. There are ten attributes that must be built in the technology designed. And the Functional Analysis Systems Technique identified the functional specification of the system. There are five main modules composed the system: filtration module, information module, high voltage module, reactor module and rack module itself.

This research was financially supported by The Faculty of Engineering, Diponegoro University, Indonesia through Strategic Research Grant 2018.

\section{References}

1. WHO/UNICEF, (World Health Organization and UNICEF). Progress on Sanitation and Drinking Water e 2015 Update and MDG Assessment. WHO, Switzerland. Available at. http://www.unicef.org/publications/index_82419.ht $\mathrm{ml}$ (2015) (accessed 10.07.18.)

2. R.C.G. Chidya, S. Matamula, O. Nakoma, C.B.J. Chawinga. Physics and Chemistry of the Earth 93 55-62 (2016)

3. A. Hazmi, R. Desmiarti, E.P. Waldi, Darwison, Journal of Engineering and Technological Sciences 45 (1) 1-8 (2013)

4. L.K. Chan, M.L. Wu, European Journal of Operational Research 143 (3) 463-497 (2002)

5. Y.Z. Mehrjerdi, International Journal of Quality \& Reliabilty Management 27 (6) 616-640 (2010)

6. J. Xu, X. Xu, S.Q. Xie, International Journal of Productivity and Quality Management 6 (4) $457-$ 494 (2010)

7. J.R. Hauser, D. Clausing, Harvard Business Review 66 63-73 (1988)

8. L. Cohen, Quality Function Deployment: How to Make QFD Work for You, Addison-Wesley, Reading, MA (1995)

9. Kaufman, J. J., Woodhead, R., Stimulating Innovation in Products and Services: With Function Analysis and Mapping. John Wiley \& Sons (2006) 